\title{
Another Overt Surface Anaphor: Norwegian 'and that'
}

\author{
HELGE LØDRUP and MARIANNE HOBÆK HAFF \\ University of Oslo
}

\section{$1 \quad$ Introduction ${ }^{1}$}

An insight from the seventies that has proved fruitful to research to this very day is the distinction between deep and surface anaphora made in Hankamer and Sag (1976). Deep anaphora are ordinary pronouns, which refer to objects in the linguistic or non-linguistic context. Surface anaphora, on the other hand, cannot be deictic; they must have a linguistic antecedent. One important example is the zero anaphor in VP and predicate ellipsis, as in (1)-(2).

(1) Have you read the book? - Yes, I have $\varnothing$

(2) Are you sure? - Yes, I am Ø

To be interpreted as an antecedent of a surface anaphor, a linguistic expression must be able to have the position of the anaphor, and satisfy standard syntactic conditions on well-formedness in this position (such as selection, theta-marking, case-marking, etc.).

Beside VP and predicate ellipsis, the sluicing construction is a surface anaphor construction. An example is (3).

\section{(3) He ran home - I don't know why $\varnothing$}

Surface anaphora are often realized as zero in English. This is not a necessary property, however. English so can be a surface anaphor with different types of antecedents. An example from Hankamer and Sag (1976:415) is (4).

(4) Look, John, your boat is sinking. - Why, so it is.

\footnotetext{
1 We would like to thank the audience at the BLS37 meeting for interesting discussion. Thanks are also due to several colleagues, especially Atle Grønn for discussing scope with us. We are also grateful to John Payne for providing information about English, and Cathrine Fabricius Hansen for providing information about German.
} 
In other Germanic languages, surface anaphora are often overt (i.e. phonologically realized). In Norwegian (and Swedish and Danish), the pronoun det 'it, that' is used as a surface anaphor with VP and predicate pronominalization (see Lødrup 1994 on Norwegian, Houser et al. 2007 on Danish, Herold 2009 on Swedish). Norwegian examples are (5)-(6).

(5) Har du lest boka? - Ja, det har jeg have you read book.DEF - yes that have I

'Have you read the book? Yes, I have'

(6) Er du sikker? - Ja, jeg er det are you sure - yes I am that 'Are you sure? Yes, I am'

The pronoun det is the central surface anaphor with VP and predicate pronominalization. It can also be used in sluicing in main or subordinate clause questions, even if this option is restricted. ${ }^{2}$ An example is (7) (where the alternative left dislocation analysis should be disregarded).

(7) Han løp hjem - Hvorfor det vet jeg ikke

he ran home - why that know I not

'He ran home - I don't know why'

Zero realization is also possible for Norwegian (and Scandinavian) surface anaphors. Zero is the normal realization with sluicing. It is also possible to some extent with VP and predicate pronominalization; it sounds best in questions and negative sentences with a very strong focus, as in (8).

(8) Jeg har funnet de vises sten - Har du virkelig Ø?

I have found the wise.GEN stone - have you really

'I have found the sorcerer's stone - Have you really?'

\section{Some General Properties of the 'and that' Construction}

This paper is about sentences like the Norwegian (9).

(9) Han løp hjem, og det i full fart

he ran home and that in full speed

'He ran home, and that at full speed'

Example (9) contains two parts. The first part is a regular clause. The second part

2 This was pointed out in Lødrup (1994). Craenenbroeck (2010) discusses this option in Dutch, also mentioning French and Norwegian. He names the construction 'spading.' 


\section{Another Overt Surface Anaphor}

consists of the coordinator $o g$ 'and', the pronoun det 'it, that' and an adjunct. (The coordinator men 'but' is possible as an alternative to $o g$ 'and'.) The pronoun takes the full clause preceding the coordinator as its antecedent, and the adjunct is interpreted as if it belongs to this clause (but see section 5).

The construction will be called the 'and that' construction. The part preceding the coordinator will be referred to as the full clause, and the rest as the reduced clause. ${ }^{3}$ The adjunct following det will be called the stranded adjunct.

This construction is very productive in Norwegian. It can also be found in some other languages (Scandinavian, German, English, French), but to our knowledge, it is hardly mentioned in the literature (but see Leira 1987 on Norwegian, and Hobæk Haff 1987:114-20, 188-92 on French). We will describe the construction, and show that det is a surface anaphor (as proposed in Lødrup 1994), and that the construction has the properties to be expected, given the theory of surface anaphora.

The antecedent

The full clause can be a main clause, as in example (9) above, or an embedded clause, finite as in (10), or non-finite as in (11). (Examples (10)-(11) are, like some other examples, edited sentences from web pages and other texts. These examples are marked 'ed txt,' while unedited text sentences are marked 'txt.')

(10) De forventer at vi skal gjøre alt riktig, og det med en gang [ed txt] they expect that we shall do everything right and that with one time 'They expect that we will do everything right, and that at once'
(11) Jeg har lyst til å denge noen, og det skikkelig [ed txt] I have urge to (PREP) to (INF.M.) beat somebody, and that properly 'I feel like beating somebody, and that properly'

The adjunct

The adjunct is usually an adverbial that is not valency-bound. It can be of any formal category that can take an adverbial function (PP, DP, CP, AdvP). The adjunct can also be a 'free' predicate, whose logical subject is the subject or object of the full clause. When it is an adjective, as in (12), it agrees with its logical subject (in number, and gender if singular).

(12) De stupte i vannet, og det nakne they dived in water.DEF and that naked.PLUR 'They dived into the water, and that naked'

\footnotetext{
3 We assume that what is coordinated is the full clause and the reduced clause. As an alternative, one could assume that the coordination is on a lower level, with the conjuncts sharing the subject. It is not easy to find arguments that could distinguish between these analyses, and the difference between them does not seem to be important to the main points of this paper.
} 
Helge Lødrup and Marianne Hobæk Haff

Word order

The reduced clause usually follows the full clause, but it can also precede a constituent of this clause, as in (13). Even then, the whole clause is understood as the antecedent. ${ }^{4}$

(13) John sa - og det med god grunn - at dette er siste gang John said and that with good reason that this is last time 'John said - and that with a good reason - that this is the last time'

Speech act

The 'and that' construction often expresses an assertion of the speaker. It does not have to be asserted, however, for example when the full clause is a conditional clause, as in (14).

(14) Ingen betaler for nyheter hvis vi leverer dem gratis, og det med bilder [ed txt]

nobody pays for news if we deliver them free and that with pictures 'Nobody pays for news if we deliver them free, and that with pictures'

\section{The 'and that' Construction and the Theory of Surface Anaphora}

We will now discuss some properties of the 'and that' construction that follow from a surface anaphor analysis.

There is a focusing effect

Like other cases of surface anaphora, the 'and that' construction has a focusing effect. The anaphor is always stressed, as overt surface anaphora usually are (Lødrup 1994), and there is also stress on the adjunct. Adjuncts that cannot be focused cannot be stranded. An important group is so-called sentence adverbs (i.e. adverbs that are usually left adjoined to VP, expressing e.g. modality, negation, focus, and speaker attitude). An example is (15). These adverbs can precede another stranded adjunct, however, as in (16).

(15) John mistet pengene, *og det sannsynligvis

John lost money.DEF and that probably

'John lost the money, and that probably'

4 It is not common that a coordination has its second conjunct within its first conjunct. However, this is also possible in another case, as in (i).

(i) John sa - og jeg forstår ham godt - at dette er siste gang

John said and I understand him well that this is last time

'John said - and I understand him well - that this is the last time'

It has been claimed that this is not real coordination (Huddleston et al. 2002:1350). 


\section{Another Overt Surface Anaphor}

(16) John mistet pengene, og det sannsynligvis i byen John lost money.DEF and that probably in city.DEF 'John lost the money, and that probably in the city'

Sentence adverbs behave in a parallel way in another focus construction, namely the cleft construction. Cleft sentences do not allow sentence adverbs to take the focus position (Faarlund et al. 1997:808). However, a sentence adverb can 'follow' a clefted constituent into the superordinate clause (compare John probably lost the money in the city and It was probably in the city that John lost the money).

There is also another parallel to cleft sentences. The Norwegian cleft construction is sometimes used without a real focus effect, especially in non-colloquial style (Faarlund et al. 1997:1092-93). The same is true of the 'and that' construction. An example is (17). This non-finite sentence gives an explanation of a word, and there can be no motivation for focusing the reduced clause.

(17) dobbelsjekke Kontrollere at ei opplysning stemmer [ .. ] double-check control that a piece.of.information is.correct 'double-check Control that a piece of information is correct og det hos ei anna skriftleg el munnleg kjelde [ed txt] and that at an other written or oral source and that with a different written or oral source'

The antecedent and the surface anaphor can belong to different utterances The full clause and the reduced clause are not necessarily a unit from the point of view of sentence grammar. The reduced clause can be contributed by a different speaker than the full clause, as in (18). This represents a general property of surface anaphora, see for example (1)-(2) and (4)-(6) above.

(18) A: Han har ikke gjort noe annet enn å feste - B: Og det hver eneste natt he has not done anything else than to party - and that every single night 'He has not done anything but partying - And that every single night'

The pronoun cannot be deictic

The pronoun cannot refer to the non-linguistic context, it can only have the full clause as its antecedent. Again, this represents a general property of surface anaphora. ${ }^{5}$ This point might seem to be contradicted by the fact that the demonstrative dette 'this' is sometimes used instead of det. An example is (19).

\footnotetext{
5 Like other surface anaphor constructions, the 'and that' construction can be used without an expressed antecedent for the surface anaphor in some cases (Merchant 2004:717-724). An unexpressed antecedent must be something that is very salient in the situation, in a way that makes it the obvious thing to say. For example, if you see a colleague drinking whiskey, you could say Og det $i$ arbeidstiden 'and that during working hours'.
} 
(19) Hun sverger på det, og dette på en troverdig måte [txt] she swears on it and this in a credible way 'She swears to that, and this in a credible way'

This demonstrative is not a real demonstrative, however; it does not allow a nonlinguistic antecedent. It should be seen as a variant of the surface anaphor.

The pronoun can (sometimes) be replaced by zero

An important fact is that the pronoun can alternate with zero in some cases, as in (20).

(20) Pillene gjorde ham frisk, og (det) på overraskende kort tid pills.DEF made him well and that in surprisingly short time 'The pills made him well, and (that) in surprisingly short time'

This alternation of a pronoun and zero in a language without pro-drop is striking. However, the alternation is natural when the pronoun is a surface anaphor, because surface anaphora can be zero.

The zero option seems to be restricted to some PP adjuncts. It is not acceptable with all PP adjuncts, as shown in (21). It is also unacceptable with adjuncts that are not PPs, an example is (22).

(21) Han løp hjem, og *(det) til tross for været he ran home and that in spite of weather.DEF 'He ran home, and that in spite of the weather'

(22) Han løp hjem, og *(det) fordi han var sulten he ran home and that because he was hungry 'He ran home, and that because he was hungry'

It is not easy to pinpoint the difference in meaning contributed by the choice between a pronoun and zero. Our general impression is that the zero option usually requires more stress and more focus (with a possible exception for some adjuncts with med 'with,' especially fixed expressions like og med god grunn 'and with good reason'). Apart from this, the construction with zero seems to have the same properties as the construction with a pronoun. ${ }^{6}$

The zero option could be compared to the zero option with VP anaphora, as in

6 Hobæk Haff (1987:114-20) (on French) discusses the zero version of the 'and that' construction together with other cases of ellipsis in coordinations, under the heading "Le second conjoint est «emphatisé»" ('the second conjunct is emphasized'). See also Hobæk Haff (1987:18891). Huddleston et al. (2002:1345-1350) (on English) classify the zero version of the 'and that' construction as "End-attachment coordination", and call it "Addition of a new element". Their example is (i).

(i) The match was won by Kim, and very convincingly too (Huddleston et al. 2002:1347) 


\section{Another Overt Surface Anaphor}

example (8) above. In both cases, the overt anaphor is the unmarked option in Norwegian, and the zero option is subject to conditions that are not clear, but seem to involve the degree of stress and focus.

\section{Grammatical Treatment}

From Hankamer and Sag (1976), an important strategy to account for surface anaphora has been to assume that a copy of the antecedent is present in the position of the surface anaphor at some level of representation. A difficult and to some extent theory internal question is what level of representation is involved. This is not the place to discuss different theories of surface anaphora. For expository purposes, we will adopt a 'naïve' syntactic approach. The basic assumption is - as in Hankamer and Sag (1976) - that a copy of the antecedent is present in the position of the surface anaphor at a 'deep' syntactic level.

In Lexical Functional Grammar, LFG, the 'deep' grammatical representation is the functional structure, with syntactic functions and morphosyntactic features. This is the level where the antecedent is represented (Levin 1982, Lødrup 1994). The 'surface' representation is the constituent structure. An overt surface anaphor is present there, while a zero anaphor is not.

The general point is that the syntax of the clause with the surface anaphor is as if the antecedent were actually present in the place of the surface anaphor. The stranded adjunct shows grammatical properties that require a full clausal representation of the surface anaphor (even if there are not many grammatical phenomena that can be realized in a structure as rudimentary as the reduced clause).

We will first discuss the syntax of the adjunct with respect to adjective agreement and phenomena related to binding: reflexive and variable binding, and principle $\mathrm{C}$ of Binding Theory. These phenomena belong to functional structure in LFG - the level of representation in which the surface anaphor is represented by (a copy of) the full clause. The prediction is that the stranded adjunct should behave just like it would if it were a part of the full clause.

\section{Agreement}

It was mentioned above that the stranded adjunct can be a free predicate, as in (12) above, reproduced as (23).

(23) De stupte i vannet, og det nakne they dived in water.DEF and that naked.PLUR 'They dived into the water, and that naked'

When the free predicate is an adjective, it must agree with its logical subject, which is the subject or object of the full clause. This follows from the clausal representation of the surface anaphor. 
Helge Lødrup and Marianne Hobæk Haff

\section{Reflexive binding}

Another relevant phenomenon is reflexive binding. A reflexive in the stranded adjunct can be bound by the subject of the full clause, as in (24). (Note that subjects bind reflexives in adjuncts in Norwegian, see Lødrup 2007.)

(24) Han produserer våpen, og det hjemme hos seg selv he produces weapons and that home at REFL self 'He produces weapons, and that in his own home'

Binding belongs to functional structure in LFG, and the binding in (24) follows from the clausal representation of the surface anaphor.

Variable binding

An example with a reflexive possessive in the stranded adjunct is (25).

(25) Hver eneste sanger fikk applaus, og det fra moren sin every single singer got applause and that from mother.DEF POSS.REFL 'Every single singer got applause, and that from his/her mother'

This example shows variable binding. The possessive is interpreted as a variable, bound by the quantifier in the subject. This kind of variable binding is known to be possible only when the quantifier is syntactically more prominent than the variable (Reinhart 1983). Prominence is understood here as defined on the relational hierarchy; the relevant level is functional structure. Again, the facts follow from the clausal representation of the surface anaphor.

Principle C

The 'and that' construction also behaves as predicted with respect to condition $\mathrm{C}$ of Binding Theory, which says that a referential expression must not be bound (Chomsky 1981:188). For example, in (26), the subject pronoun in the full clause cannot corefer with the proper name in the stranded adjunct.

(26) Han ble kastet ut, og det av Johns mor he was thrown out and that by John.GEN mother 'He was thrown out, and that by John's mother'

Again, this follows from the clausal representation at functional structure, where the pronoun is syntactically more prominent than the proper name.

\section{Scope}

The 'and that' construction does not necessarily have the same meaning as the 


\section{Another Overt Surface Anaphor}

corresponding simple clause without 'and that.' Negation and focus adverbs cannot scope over a stranded adjunct. ${ }^{7}$ Their scope is known to be sensitive to focus structure in the surface realization of the sentence, and at this level, the surface anaphor has replaced (the copy of) the full clause. In (27), the PP is the preferred scope of bare 'only.' In (28) with the 'and that' construction, this PP is a stranded adjunct, and it cannot be the scope of bare 'only.' Instead, the verb must be the scope in (27).

(27) Han danser bare med Marit he dances only with Marit 'He dances only with Marit'

(28) Han danser bare, og det med Marit he dances only and that with Marit 'He dances only, and that with Marit'

To some extent, it is possible to scope over the stranded adjunct by placing the adverb in front of it, as in (29). (This adverb placement is discussed in section 3, see example 16.)

(29) Han danser, og det bare med Marit he dances and that only with Marit 'He dances, and that only with Marit'

Negation behaves in the same way as focus adverbs. In the text example (30), the negation cannot scope over the stranded adjunct, and one gets the impression that this is the reason the 'and that' construction is used. ${ }^{8}$

$7 \quad$ Quantifiers behave as expected with the surface anaphor analysis. For example, (i) is ambiguous, allowing the quantifiers to take high or low scope, just like the corresponding sentence without 'and that.'

(i) Mange mennesker går over fjellet, $\quad$ og det hver dag many people walk across montain.DEF and that every day 'Many people walk across the mountain, and that every day'

8 Examples (i)-(ii) also show that the stranded adjunct cannot be the scope of a focus adverb in the full clause.

(i) Det var bare jeg som fikk anmerkning i meldingsboka mi it was only I who got bad.mark in message.book.DEF my

'It was only I who got a bad mark in my message book'

(ii) Det var bare jeg som fikk anmerkning - og det i meldingsboka mi it was only I who got bad.mark and that in message.book.DEF my 'It was only I who got a bad mark and that in my message book'

These examples were constructed by Atle Grønn, who points out that (i) and (ii) have different interpretations. In (i), the alternative set actualized is a set of students who could have gotten bad marks in their message books. In (ii), on the other hand, the alternative set is a set of students who could have gotten bad marks - not necessarily in their message books. 
Helge Lødrup and Marianne Hobæk Haff

(30) De har ikke byttet ut sverdene og det for å vekke guttenes interesse [txt] they have not replaced PART swords.DEF and that to arouse boys.DEF.GEN interest

'They have not replaced the swords, and that to arouse the boys' interest'

\section{$6 \quad$ An Alternative Analysis Rejected}

The facts presented in section 4 rule out a possible alternative analysis of the 'and that' construction. In this alternative analysis, the pronoun is a 'deep' pronoun referring to the event of the full clause, and there is a silent light verb in the second conjunct. According to this alternative analysis, the structure is as in (31).

(31) Han løp hjem, og det skjedde i full fart he ran home and that happened in full speed 'He ran home, and that happened at full speed'

There are several arguments against a missing verb analysis. It is often not clear what verb should be inserted to make an acceptable sentence, e.g. in sentences with stative verbs such as (32). When the full clause is non-finite, a verb is not enough - an auxiliary and a tense would have to be inserted as well. An example is (11) above, reproduced as (33).

(32) Jeg var stolt, og det til tross for at resultatet kunne vært bedre [ed txt] I was proud and that in spite of that result.DEF could been better 'I was proud, and that even if the result could have been better'

(33) Jeg har lyst til å denge noen, og det skikkelig [ed txt] I have urge to (PREP) to (INF.M.) beat somebody, and that properly 'I feel like beating somebody, and that properly'

More important arguments are given by the phenomena discussed in section 4 . The missing verb analysis does not work when the adjunct is a free predicate. Example (34) (based upon example 12/23) is ungrammatical, because the free predicate does not get the right kind of subject.

(34) De stupte i vannet they dived into water.DEF

*og det skjedde naken / nakent / nakne and that happened naked.MASC.SG / naked.NEUT.SG / naked.PLUR

The reason for the ungrammaticality is not only the agreement problem; (34) would also be ungrammatical with a non-agreeing adjective (such as beruset 'intoxicated'). 


\section{Another Overt Surface Anaphor}

The missing verb analysis is also unable to predict the binding facts. It could not relate the reflexive to its binder in example (24), reproduced as (35), because han 'he' and the reflexive are not parts of the same clause at any level of representation. When a light verb is inserted in (35), a non-reflexive pronoun is the only option, as shown in (36). ${ }^{9}$

(35) Han produserer våpen, og det hjemme hos seg selv he produces weapons and that home at REFL self 'He produces weapons, and that in his own home'

(36) Han produserer våpen, og det skjer hjemme hos ham selv / * $\underline{\text { seg selv }}$ he produces weapons and that happens home at him self / REFL self 'He produces weapons, and that happens in his own home'

\section{$7 \quad$ Other Languages}

It was shown that Norwegian uses the pronoun det 'it, that' in the 'and that' construction - and to some extent dette 'this.' As mentioned in section 1, det is also used in the other constructions with surface anaphora: VP and predicate pronominalization, and sluicing.

The 'and that' construction can also be found in English, French, and German. These languages also show - to a varying degree - an overlap between the forms used in the 'and that' construction and the forms used in other surface anaphor constructions.

In the German example (37), the pronoun das 'that' is used. The demonstrative dies 'this' is also possible, as in (38).

(37) Batman lebt und das in Corpus Christi [txt]

Batman lives and that in Corpus Christi

'Batman lives and that in Corpus Christi'

(38) Irland bietet für jeden etwas. Und dies auf typisch irische Art [txt]

Ireland offers for everybody something and this in typical Irish way

"Ireland offers something for everybody. And this in a typical Irish way"

9 Another alternative analysis has been suggested to us, in which the 'and that' construction is derived from the gjøre det 'do that' construction. The structure in then really as in (i).

(i) Han løp hjem, og han gjorde det i full fart

he ran home and he did that in full speed

'He ran home, and he did that at full speed'

It could be noted that the gjøre det 'do that' construction is also a surface anaphor construction, a type of VP pronominalization (Lødrup 1994). One important argument against the analysis in (i) is that it depends upon the fact that Norwegian uses the same pronominal form in the 'do that' construction and the 'and that' construction. The analysis cannot be transferred to languages that do not have a 'do that' construction using the same form as the 'and that' construction - for example English and French (see section 7). 


\section{Helge Lødrup and Marianne Hobæk Haff}

German has VP and predicate pronominalization (Herold 2009). These constructions take das 'that' as the central surface anaphor, just like the 'and that' construction (even if es 'it' is also possible in some cases). An example with VP pronominalization is (39).

(39) Hast du das Buch gelesen? - Ja, das habe ich.

have you the book read - yes that have I

'Have you read the book? - Yes, I have'

In the French example (40), the pronoun ce 'it, that' is used (Hobæk Haff 1987:114-20, 188-92).

(40) Nous n'en citerons que quelques-unes, et ce à titre indicatif [txt] we NEG thereof cite only some and that to title indicative 'We only cite some of them, and that as a guide'

As in Norwegian and German, (more) demonstrative forms can also be used, namely cela and ça 'it, that,' as in (41) and (42).

(41) Tu es mon frère et cela pour toujours [txt] you are my brother and that for always

'You are my brother, and that forever'

(42) Je t'aime, et ça depuis 8 ans [txt]

I you love and that since 8 years

'I have now loved you for 8 years'

The form ça is also used in sluicing (Craenenbroeck 2010), an example is (43). ${ }^{10}$

(43) A: Je vais à Londres B: Quand ça? (Craenenbroeck 2010:103)

I go to London - when that

'I am going to London. When?'

English uses the pronoun that in the 'and that' construction, as in example (44), or the demonstrative this, as in (45). (The example sentences are from the British National Corpus, thanks to John Payne.)

10 French differs from Scandinavian and German in that there is no regular VP pronominalization (and no VP ellipsis, Lobeck 1995). Predicate pronominalization is possible, however, with a different form, namely le 'it.' An example is (i).

(i) Êtes-vous directrice? Oui, je le suis (Cornish 1986:116)

are you (female)director - yes I it am

'Are you a (female) director? Yes, I am' 
(44) I had to take one step every two minutes, and that in slow motion

(45) Rob Andrew has, as he himself admits, only recently begun to display his Wasps form for England - and this after 26 caps

Standard English differs from the other languages mentioned in that the forms used in the 'and that' construction are not found as surface anaphora in other constructions. There are dialects, however, that use that with predicate pronominalization, Huddleston et al. (2002:1538 note 50) give (46)-(47) as examples of responses to It's an absolute swindle. (The \% signs indicate dialectal variation.)

(46) \% That it is

(47) \%It is that

We see, then, that all the languages discussed - including English, if non-standard forms are taken into account - show an overlap between the set of forms used in the 'and that' construction and the set of forms used in other surface anaphor constructions.

\section{Conclusion}

Overt surface anaphora are found in a small family of constructions, which includes VP and predicate pronominalization, and sluicing (and possibly the case discussed in Lødrup 2012). The surface anaphor discussed here extends this family. Overt surface anaphora raise several theoretical challenges, especially concerning their relation to ellipsis. These must be left to future research.

\section{References}

Chomsky, Noam. 1981. Lectures on Government and Binding. Dordrecht: Foris.

Cornish, Francis. 1986. Anaphoric Relations in English and French: A Discourse Perspective. London: Croom Helm.

Craenenbroeck, Jeroen van. 2010. The Syntax of Ellipsis: Evidence from Dutch Dialects. New York: Oxford University Press.

Faarlund, Jan Terje, Svein Lie and Kjell Ivar Vannebo 1997 Norsk referansegrammatikk. Oslo: Universitetsforlaget.

Hankamer, Jorge and Ivan A. Sag. 1976. Deep and surface anaphora. Linguistic Inquiry 7(3):391-426. 
Helge Lødrup and Marianne Hobæk Haff

Herold, Jenny Ström. 2009. Proformen und Ellipsen: Zur Syntax und Diskurspragmatik prädikativer Anaphern im Deutschen und im Schwedischen. Lunder germanistische Forschungen 70. Visby: eddy.se.

Hobæk Haff, Marianne. 1987. Coordonnants et éléments coordonnés. Oslo: Solum. Diffusé en France par Didier Érudition.

Houser, Michael J., Line Mikkelsen, and Maziar Toosarvandani. 2007. Verb phrase pronominalization in Danish: Deep or surface anaphora? In Erin Brainbridge and Brian Agbayani (eds.) Proceedings of the Thirty-Fourth Western Conference on Linguistics, 183-195. Fresno CA: Department of Linguistics, California State University.

Huddleston, Rodney, John Payne and Peter Peterson. 2002. Coordination and supplementation. In Rodney Huddleston and Geoffrey K. Pullum (eds.) The Cambridge Grammar of the English Language, 1273 - 1362. Cambridge: Cambridge University Press.

Leira, Vigleik. 1987. Uttrekking - syntagmetypen "og det ...". Maal og Minne 1987:208-210.

Levin, Lori S. 1982. Sluicing: A lexical interpretation procedure. In Joan Bresnan (ed.) The Mental Representation of Grammatical Relations, 590-654. Cambridge, MA: MIT Press.

Lobeck, Anne. 1995. Ellipsis. Functional Heads, Licensing, and Identification. Oxford: Oxford University Press.

Lødrup, Helge. 1994. "Surface proforms" in Norwegian and the Definiteness Effect. In Mercé Gonzalez (ed.) Proceedings of the North East Linguistics Society 24, 303-315. Amherst: GLSA, Department of Linguistics, University of Massachusetts.

Lødrup, Helge. 2007. A new account of simple and complex reflexives. Journal of Comparative Germanic Linguistics 10(3):183-201.

Lødrup, Helge. 2012. Some Norwegian 'type anaphora' are surface anaphora. Journal of Germanic Linguistics 24(1):23-52.

Merchant, Jason. 2004. Fragments and ellipsis. Linguistics and Philosophy 27(6):661-738. 


\section{Another Overt Surface Anaphor}

Reinhart, Tanya. 1983. Anaphora and Semantic Interpretation. London: Croom Helm.

Helge Lødrup

University of Oslo

Department of Linguistics and Scandinavian Studies

$\mathrm{Pb}$ 1102, Blindern, NO-0317 Oslo, Norway

helge.lodrup@ilf.uio.no

Marianne Hobæk Haff

University of Oslo

Department of Literature, Area Studies and European Languages

$\mathrm{Pb}$ 1003, Blindern, NO-0315 Oslo, Norway

m.h.haff@ilos.uio.no 